\title{
Configurações
}

Revista de sociologia

$24 \mid 2019$

Imaginar "futuros" do trabalho, contextos e vivências subjetivas

\section{Ana Paula Marques (2009), Trajetórias Quebradas: A vivência do desemprego de longa duração. Porto ProfEdições/ CICS-UM}

Maria Zênia Tavares da Silva

\section{OpenEdition}

\section{Journals}

Edição electrónica

URL: http://journals.openedition.org/configuracoes/7814

DOI: $10.4000 /$ configuracoes.7814

ISSN: 2182-7419

Editora

Centro de Investigação em Ciências Sociais

Edição impressa

Paginação: 122-125

ISSN: 1646-5075

\section{Refêrencia eletrónica}

Maria Zênia Tavares da Silva, «Ana Paula Marques (2009), Trajetórias Quebradas: A vivência do

desemprego de longa duração. Porto ProfEdições/ CICS-UM », Configurações [Online], 24 | 2019, posto online no dia 18 dezembro 2019, consultado o 24 setembro 2020. URL : http://

journals.openedition.org/configuracoes/7814; DOI : https://doi.org/10.4000/configuracoes.7814 
Silva, Maria Zénia Tavares da - Ana Paula Marques (2009), Trajetórias Quebradas: A vivência do desemprego de longa duração. Configurações, vol. 24, 2019, pp. 122-125.

\section{Ana Paula Marques (2009), Trajetórias Quebradas: A vivência do desemprego de longa duração. Porto ProfEdições/ CICS-UM}

MARIA ZÊNIA TAVARES DA SILVA*

Universidade Federal Rural de Pernambuco, Brasil

A obra Trajetórias Quebradas: A vivência do desemprego de longa duração discute a vivência subjetiva de homens e mulheres em situação de desemprego de longa duração, a partir da realização de dois estudos de casos, um no Concelho de Espinho e outro em Guimarães, localizados no Norte de Portugal. O estudo teve como hipótese que "as sucessivas experiências de privação de emprego e a acumulação de rupturas de laços sociais permitem definir percursos profissionais vulneráveis ao desemprego e à exclusão social de certos grupos sociais face ao mercado de trabalho" (p. 15). Os principais resultados da investigação são apresentados em duas partes no livro. A primeira aborda uma discussão teórica, intitulada "Mercado de trabalho e a 'invenção do desemprego", e a segunda, "Trajectórias quebradas: A vivência do desemprego", que versa sobre as narrativas obtidas em contexto de entrevistas biográficas. A relevância em investigar sobre a vivência subjetiva de homens e mulheres em situação de desemprego de longa duração justifica-se pela necessidade de identificar quem são os/as desempregados/as de longa duração, e "contribuir para combater alguns estereótipos associados de modo a sensibilizar as instâncias decisoras e o cidadão, em geral, para as dimensões de vulnerabilidade social, psicológica e identitária que atingem grupos sociais cada vez mais diversificados” (p. 13).

A forma de apresentação do livro facilita a leitura, tornando-a compreensível e dinâmica. Logo no início é definida a hipótese e os objetivos da investigação, seguida de duas partes fundamentais, uma que trata dos aspectos

* Doutoranda em Sociologia, Instituto de Ciências Sociais, Universidade do Minho.

Email: zeniatavares@yahoo.com.br 
teóricos e estatísticos do tema, e outra que aborda as questões metodológicas e resultados da pesquisa.

$\mathrm{Na}$ Parte I do livro, a autora busca apresentar as principais contribuições referente ao mercado de trabalho e a "invenção" do desemprego, com destaque nas consequências sociais do desemprego. Chama atenção que uma proposta inovadora de conceito de desemprego só será possível ao investir em um enfoque multidimensional do desemprego que permita "ultrapassar as abordagens insuficientes de pendor económico e, por outro, equacionar as relações de trabalho e de emprego/desemprego a partir dos processos sociais que estão simultaneamente na sua origem e sentido" (p. 19). Propõe, consequentemente que sejam contempladas análises de aspectos sociológicos, antropológicos e históricos para restabelecer "toda complexidade e variabilidades económicas, sociais e culturais dos mercados de trabalho" (ibidem). As dimensões sociais, políticas e simbólicas passaram também a fazer parte da análise do mercado de trabalho, além da relação custo e benefícios, características das análises económicas.

Para a autora, analisar o mercado de trabalho a partir do enfoque sociológico, abrange um "tipo particular de relação social institucionalizada que envolve produção, consumo e troca” (p. 21). Incide em analisar as estruturas do mercado de trabalho, em detrimento de análises centradas no indivíduo, por se constituírem num "espaço onde se cruzam, sobrepõem e articulam atores e estratégias diferenciadas, não necessariamente coincidentes entre si” (ibidem).

Além de uma revisão crítica das principais contribuições teóricas sobre o mercado de trabalho, a autora também aborda a importância de dados estatísticos para analisar o fenómeno do desemprego de longa duração a partir de informações oficiais, referentes aos dois concelhos estudados. Complementa esta "radiografia" dos indicadores disponíveis do mercado de trabalho a nível local, nacional e europeu, com a realização de entrevistas biográficas (história de vida), sendo esta a abordagem privilegiada na investigação de Marques. Neste sentido, apresenta os critérios que definiram a opção pela abordagem qualitativa, com o seguinte roteiro: (1) opções e cautelas metodológicas; explicitação dos critérios de seleção; entrevistas biográficas; análise temática; (2) caracterização do perfil de desempregados de longa duração.

$\mathrm{Na}$ Parte II do livro, além de abordar o percurso da investigação, a autora expõe os principais resultados da vivência subjectiva do desemprego de longa duração, tendo permitido identificar algumas das consequências (in)visiveis mais significativas no quadro da investigação, designadamente: pessoas com intenções de cometer suicídio; acompanhamento psicológico e/ou psiquiátrico; disfunções familiares (e.g. divórcio, isolamento, retirada de filhos menores); situações de desespero económico, comportamentos de resistência e de luta por melhores condições de vida.

O universo da pesquisa foi composto por grupos sociais mais vulneráveis ao desemprego, com destaque às mulheres, pois embora com um aumento no 
índice de atividade profissional, o desemprego e o vínculo de trabalho mais precários, são mais constantes em suas vidas. Além desses grupos, também participaram da pesquisa jovens com mais escolaridade. Foram realizadas catorze entrevistas biográficas nos dois Concelhos, oito no conselho de Espinho e seis no concelho de Guimarães. As entrevistas biográficas foram realizadas por meio de um guião semi-estruturado constituído de três eixos: “1) Percurso escolar e profissional; 2) Contextos e percepções do desemprego e 3) Estratégias e expectativas de resignação/superação do desempregado" (p. 64). De acordo com a autora, conhecer as principais barreiras para o ingresso ao mercado de trabalho e as estratégias para superá-las "pode contribuir para o desenvolvimento de adequadas políticas públicas de emprego, formação e cidadania" (p. 64). Com o objetivo de construir instrumentos (grelhas) para decodificar e compreender o sentido, a partir dos autores utilizados na matriz teórica da investigação, a análise do corpus das entrevistas incidiu em: "leitura, classificação e transcrição atenta do texto oral...; clarificação do corpus composto por informações sobre acontecimentos...; compreensão e organização do corpus a partir de grelhas de análise temática; e comparação e distinção das histórias (p. 65). Sob orientação da pertinência teórica, as narrativas biográficas foram reconstruídas e examinadas a fim de compreender o fenômeno analisado.

A partir das dimensões da experiência social do desemprego, Marques apresenta alguns fatores que podem explicar o desemprego, como a baixa escolaridade e a instabilidade profissional, especificamente numa conjuntura globalizada. Destes percursos escolares e profissionais vulneráveis reforça-se a precária diversidade económica (basicamente indústria têxtil, confecção, vestuário, calçado, cortiça e alimentação), na região Norte de Portugal, além da eliminação de alguns sectores de trabalho, e consequentemente a redução no número de trabalhadores e diminuição de salários. Outros resultados são explorados ao longo da obra, em especial os que se relacionam com estratégias e expectativas de resiganção ou superação do desemprego.

A partir do enfoque téorico privilegado pelo autora, foi possível "desocultar” as consequências diferenciadas das provações do desemprego de longa duração, permitindo compreender, sobretudo, “i) riscos de dissociação de laços sociais; ii) relação consigo próprio e auto-estima; iii) emergência de quadros de doença e psicopatologias” (p. 83). Assim, na investigação foi constatado que tanto em nível de empresa, colegas de trabalho, família e amigos, os laços são intensamente afetados, tendo em vista o isolamento por parte da pessoa desempregada, que a privação econômica condiciona, o que provoca "um empobrecimento cultural e lúdico" (p. 85). O afastamento do convívio social, pode gerar um movimento cascata, isto é, levar a situação/sentimento de solidão e sofrimento, perda de auto-estima, bem como falta de segurança, desmotivação e apatia. O que por sua vez, pode acarretar doenças e psicopatologias. Antes de concluir, a autora apresenta cinco biografias onde enfatiza as dimensões 
associadas a baixa auto-estima, desestruturação familiar, debilidade física e emocional, bem como dificuldades econômicas de quem vivencia o desemprego por um longo período. Finaliza o livro com um alerta sobre a degradação da condição de vida que a falta de emprego pode provocar, além do afastamento da vida social, e o risco de levar indivíduos a situação de extrema pobreza.

É um livro que nos instiga a reflexão sobre a importância de tratar o desemprego não só pelo viés econômico, mais sobretudo, político, social e subjetivo. Trata-se de um tema caro e complexo à população, tendo em vista as consequências econômicas, sociais e emocionais que o desemprego pode ocasionar em quem vivencia essa situação em longa permanência, além de consequências negativas para sociedade. 